\title{
ASSESSMENT OF POSSIBLE SYNERGISTIC EFFECT OF BISPHOSPHONATES AND STATINS IN MURINE EXPERIMENTAL TOXOPLASMOSIS GONDII
}

\author{
By \\ NADA R. MOHAMED ${ }^{1}$, AZZA I. H. YOUNIS ${ }^{1}$, RABAB S. ZALAT ${ }^{2}$, \\ and NAGLAA F.A. IMAM ${ }^{1^{*}}$ \\ Department of Medical Parasitology, Faculty of Medicine, Cairo University ${ }^{1}$ and \\ Department of Medical Parasitology, Theodore Bilharz Research Institute ${ }^{2,}$ Imbaba \\ P.O. Box 30, Giza ( ${ }^{*}$ Correspondence: naglaa-fouad@cu.edu.eg, ORCID ID: \\ https://orcid.org/0000-0002-3172-8980)
}

\section{Abstract}

This open new horizons for drug repositioning to standard used drugs in treatment of acute toxoplasmosis. This study was conducted on 70 male Albino mice in Theodore Bilharz Research Institute (TBRI) to evaluate the possible synergistic effect of risedronate sodium (Bisphosphonates) combination with atorvastatin (statins) on acute Toxoplasma gondii (RH strain) infected mice versus the drug spiramycin (macrolides). Drug combination was used in two doses: the first combined dosage was $0.01 \mathrm{mg} / \mathrm{kg} /$ day risedronate sodium and $1.25 \mathrm{mg} / \mathrm{kg} /$ day atorvastatin $(\mathrm{G} \mathrm{B}+\mathrm{S} 1)$ and the second one was $0.2 \mathrm{mg} / \mathrm{kg} /$ day risedronate sodium and 20 $\mathrm{mg} / \mathrm{kg}$ /day atorvastatin ( $\mathrm{G} \mathrm{B}+\mathrm{S} 2)$ and each drug of them was also used alone at a dose of 0.4 $\mathrm{mg} / \mathrm{kg} /$ day for risedronate sodium (G B) and $40 \mathrm{mg} / \mathrm{kg} /$ day for atorvastatin (G S) in comparison to spiramycin (G M) which was used at a dose of $200 \mathrm{mg} / \mathrm{kg} /$ day.

Microscopy examination by Giemsa stained of peritoneal exudate from $T$. gondii infected mice showed reduction in number of Toxoplasma tachyzoites to $86.28 \%$ on the $5^{\text {th }}$ day post infection (G B+S1), 98.35\% in (G B+S2), 98.27\% in (G B) and $85.03 \%$ in (G S) and spiramycin treated mice with reduction of $93.66 \%$. Histopathological examination of liver sections collected from infected mice showed remarked significant improvement in mice treated with combined of risedronate sodium and atorvastatin.

Key words: Mice, Toxoplasma gondii, Risedronate sodium, Atorvastatin, Spiramycin.

\section{Introduction}

Toxoplasma gondii (T. gondii) is a worldwide distributed intracellular parasite that affected about 1 billion of people (Pagheh et $a l, 2020)$. The highest rates of infection with T. gondii were reported in Europe, Central America, Brazil, and Central Africa (Berger et al, 2009). In some Arabian Countries the toxoplasmosis among women ranged from 22.5 to $37.4 \%$ in Saudi Arabia (Shoura et al, 1973; Abbas et al, 1986), 37.5\% in Libya (Kassem and Morsy, 1991), 37\% in Jordan (Morsy and Michael, 1980), and 22.2\% pregnant women and 20\% non-pregnant ones in Egypt (Saleh et al, 2014). Al-Kappany et al. (2010) in Egypt isolated T. gondii from cats, Saleh et al. (2016) considered toxoplasmosis as an occupational disease, and Abass et al. (2020) reported toxoplasmosis in humans and edible and stray animals.
Toxoplasmosis causes serious manifestations, particularly in the immunocompromised persons as encephalitis, fatal pneumonia and/or disseminated infection. Acute toxoplasmosis in pregnant women may cause serious health problems to the fetus (congenital toxoplasmosis), including mental retardation, seizures, blindness, and death, or manifestations may not appear until the second or third decade of life (Dolores et al, 2015). Serologic tests are used to diagnose acute infection in pregnant women, but false-positive tests occur frequently, thus, serologic diagnosis must be confirmed at a reference laboratory before treatment with potentially toxic drugs should be considered (Jones et al, 2003). The commercial anti-toxoplasmosis drugs are Pyrimethamine, sulfadiazine (McAuley et al, 2009), Pyrimethamine-sulfadiazine with folic acid (Wishahy et al, 1971) and 
Clindamycin-atovaquone combination (Azevedo Silva et al, 2019). But, the drugs may cause side-effects (D'angelo et al, 2008), or may be ineffective against cysts (Boyom et $a l, 2014)$. Toxoplasmosis was treated also with Spiramycin, which more or less not effective, and infection may develop resistance (Montazeri et al, 2017). Thus, development of new anti-toxoplasmosis with high efficacy and less side effects was a mandatory (Zhang et al, 2019).

To overcome the huge cost of the de novo drug development, the ongoing medications were evaluated as new drug repurposing (repositioning) that alternated alternative to de novo drug (Ashburn and Thor, 2004). Isoprenoids are compounds essential for all cells and most apicomplexans due to their active role in many biological processes, and enzymes, involved in this pathway by acting as molecular targets for drugs against parasites (Moreno and Li, 2008). T. gondii was unable to make its own isoprenoids, but can do with specific intermediate host cells. Bisphosphonates (FDA) and Statins (FDA) inhibited isoprenoid pathway in parasitosis by blocking their growth in the host cell (Li et al, 2017).

This study aimed to evaluate double-hit strategy of combining inhibitors of host isoprenoid pathway for more potent as a safe anti-Toxoplasma drug.

\section{Materials and Methods}

A total number of 70 laboratory bred male Swiss albino mice, aged 6-8 weeks and weighed 20-30gm, C57BL/6 strain were purchased from The European Country Farms in Egypt. They were housed in Theodor Bilharz Research Institute (TBRI) during the study period (June 2019 to August 2019). Mice were kept on a standard diet of $24 \%$ protein, $4 \%$ fat, $4-5 \%$ fiber and water ad-libitumin in plastic cages at room temperature of $21^{\circ} \mathrm{C}$ and $60 \%$ humidity.

Ethical consideration: Protocol was approved by Faculty of Medicine, Cairo University and, TBRI Ethical Committee. All procedures related to experimented-with mice were treated due to the ethical standards ap- proved after Declaration of Helsinki (1964).

Drugs: 1- Spiramycin: 3 million international units (M.I.U) was used in a tablet form provided by Pharaonia Pharmaceuticals (analytical standard code: J01FA02). Tablets were smashed into powder which was dissolved in phosphate buffered saline (PBS) and each tablet dissolved in $12 \mathrm{ml}$ PBS in labeled drug containers that were stored in refrigerator at $4 \pm 2{ }^{\circ} \mathrm{C}$ (Garcia, 2007). Drug was given orally to mice by an esophageal tube. Spiramycin was given at a dose of $200 \mathrm{mg} / \mathrm{kg} /$ day for 5 consecutive days (Abdel Hamed et al, 2019). 2- Risedronate sodium pure crystalline powder was kindly provided by Future Pharmaceutical Industries (analytical standard code: UT/STS/API/054-03/A). It was prepared as stock solutions of different doses by dissolving the powder in PBS (4mg risedronate sodium in $100 \mathrm{ml}$ BPS, $2 \mathrm{mg}$ risedronate sodium in $100 \mathrm{ml}$ BPS and $1 \mathrm{mg}$ risedronate sodium in $1000 \mathrm{ml}$ BPS). It was given to mice by intraperitoneal (IP) by disposable insulin syringe (Erhirhie et al, 2014). Also, solutions were stored in the refrigerator at $4 \pm 2^{\circ} \mathrm{C}$, in labeled containers (London and East, 2001). Three different doses of risedronate sodium were prepared $0.4 \mathrm{mg} / \mathrm{kg} / \mathrm{day}$; $0.2 \mathrm{mg} / \mathrm{kg} /$ day, $\& 0.01 \mathrm{mg} / \mathrm{kg} /$ day, each dose was given to infected mice for 5 consecutive days (Li et al, 2017). 3- Atorvastatin, in pure powder was provided by DELTA PHARMA (analytical standard code: AVN1ATA11B), and prepared as stock solutions of different doses by dissolving the atorvastatin powder in PBS as $400 \mathrm{mg}$ in $100 \mathrm{ml}$ BPS, $200 \mathrm{mg}$ in $100 \mathrm{ml}$ BPS \& $12.5 \mathrm{mg}$ in $100 \mathrm{ml}$ BPS and given to mice by IP by insulin syringe (Erhirhie et al, 2014), and labeled prepared solutions were also stored in the refrigerator at $4 \pm 2^{\circ} \mathrm{C}$. Atorvastatin in a dose of $40 \mathrm{mg} / \mathrm{kg} /$ day (G S) was given alone to infected mice. Besides, Atorvastatin in a dose of $1.25 \mathrm{mg} /$ $\mathrm{kg} /$ day combined with risedronate sodium in a dose $0.01 \mathrm{mg} / \mathrm{kg} /$ day $(\mathrm{G} \mathrm{B}+\mathrm{S} 1)$ and atorvastatin in a dose of $20 \mathrm{mg} / \mathrm{kg} /$ day combined with risedronate sodium in a dose of $0.2 \mathrm{mg} /$ $\mathrm{kg} /$ day $(\mathrm{G} \mathrm{B}+\mathrm{S} 2)$ each dose for 5 consecuti- 
ve days (Li et al, 2017).

Tachyzoites was obtained from peritoneal exudate on $3^{\text {rd }}$ day post passage (Michael et $a l$, 1979). Peritoneal exudate was diluted with PBS (Eissa et al, 2012). Each mouse was infected by IP with $20 \mu 1$ of 10-20 tachyzoites in PBS (Li et al, 2017). Drugs evaluation was shown in the following table.

Table 1: Study design for acute experimental toxoplasmosis in mice groups.

\begin{tabular}{|c|c|}
\hline Group & Mice (ten each) \\
\hline$(\mathrm{N})$ & Non-infected non treated naïve mice (negative control) \\
\hline$(\mathrm{M})$ & Infected mice received Spiramycin ${ }^{(\mathbb{R}}$ in a dose of $200 \mathrm{mg} / \mathrm{kg} /$ day (Grujić et al, 2005). \\
\hline$(\mathrm{S})$ & Infected mice received Atorvastatin $^{(B)}$ in a dose of $40 \mathrm{mg} / \mathrm{kg} / \mathrm{day}(\mathrm{Li}$ et al, 2017) \\
\hline$(\mathrm{B}+\mathrm{S} 1)$ & $1^{\text {st }}$ combined dose $0.01 \mathrm{mg} / \mathrm{kg} /$ day Risedronate sodium $\& 1.25 \mathrm{mg} / \mathrm{kg} /$ day Atorvastatin infected mice (Li et al, 2017). \\
\hline$(\mathrm{B}+\mathrm{S} 2)$ & $2^{\text {nd }}$ combined dose $0.2 \mathrm{mg} / \mathrm{kg} /$ day Risedronate sodium \& $20 \mathrm{mg} / \mathrm{kg} /$ day atorvastatin infected mice ( $\mathrm{Li}$ et al, 2017). \\
\hline
\end{tabular}

(N: naïve group, C: infection control, M (macrolides): spiramycin $200 \mathrm{mg} / \mathrm{kg}, \mathrm{B}$ (bisphosphonates): risedronate sodium $0.4 \mathrm{mg} / \mathrm{kg}, \mathrm{S}:$ atorvastatin $40 \mathrm{mg} / \mathrm{kg}, \mathrm{B}+\mathrm{S} 1$ : (bisphosphonates \& statins): Risedronate sodium $0.01 \mathrm{mg} / \mathrm{kg} \&$ atorvastatin $1.25 \mathrm{mg} / \mathrm{kg}, \mathrm{B}+\mathrm{S} 2$ (bisphosphonates \& statins): risedronate sodium $0.2 \mathrm{mg} / \mathrm{kg}+$ atorvastatin $20 \mathrm{mg} / \mathrm{kg}$ ).

Drugs were given for 5 days from day zero post infection (PI) and Ketoprofen was allowed orally in dose of $2 \mathrm{mg} / \mathrm{kg} / \mathrm{body} / \mathrm{mouse}$ to manage pain (Dobromylskyj et al, 2000). On $5^{\text {th }}$ day post-infection mice were anesthetized with thiopental (Liang et al, 1987) and sacrificed. Drug efficacy was evaluated parasitological by tachyzoites number in peritoneal exudate (Al-Dakhil and Morsy, 1996), and histopathological by liver tissue for inflammations degree (Drury and Wallington, 1980). Liver inflammation and injury were assessed by using the Ishak modification of Knodell B hepatic activity index to measures intensity of inflammation and detection of architectural alteration (Theise, 2007).

Statistical analysis: Data were coded and entered using the statistical package for the Social Sciences (SPSS) version 25 (IBM Corp., Armonk, NY, USA). Data was summarized using mean \pm standard deviation in quantitative data. Comparisons between variables were done using nonparametric Kruskal-Wallis and Mann-Whitney tests. For comparison, Chi square $(\chi 2)$ test was used. Exact test was used instead when expected frequency $<5$. $\mathrm{P}$ value less than 0.05 were considered as statistically significant.

\section{Results}

Infected mice showed that tachyzoites/ 20 $\mu l$ exudate was $42511 \pm 3926$, but in spiramycin treated mice number was reduced to $2695 \pm 396$ with significant reduction $93.66 \%$ ( $\mathrm{P}=0.003)$. Risedronate sodium mice treated with $0.4 \mathrm{mg} / \mathrm{kg} /$ day showed a significant reduction of $736 \pm 102$ with $98.27 \%(\mathrm{P}<0.001)$.
Tachyzoites in mice treated with atorvastatin $40 \mathrm{mg} / \mathrm{kg} /$ day was reduced to $6363 \pm 1491$ with insignificant reduction to $85.03 \%$ ( $\mathrm{P}=$ $0.179)$. Tisedronate sodium mice treated with $0.01 \mathrm{mg} / \mathrm{kg} /$ day combined with $1.25 \mathrm{mg} / \mathrm{kg}$ /day atorvastatin was reduced to $5832 \pm$ 1169 with insignificant reduction of $86.28 \%$ ( $\mathrm{P}=0.106)$, but mice treated with $0.2 \mathrm{mg} / \mathrm{kg} /$ day risedronate sodium combined with 20 $\mathrm{mg} / \mathrm{kg} /$ day atorvastatin number was reduced to $703 \pm 525$ with significant reduction of $98.35 \%$ ( $\mathrm{P}=$ zero $)$.

The histopathological evaluation depended on the degree of portal, lobular and interface inflammation. The intensity of inflammation was interpreted into specific score (Ishak score) according to heaviness of the cellular infiltration and presence of lymphocytic aggregation (Theise, 2007). These results were compared to the histopathological results of the naïve group that showed normal liver tissue with normal architecture of hepatic lobules and normally arranged polygonal hepatocytes. Histopathological examination in the infection control group showed that $16.7 \%$ of acute infected mice had score 1 in portal inflammation, $66.6 \%$ had score 2 and $16.7 \%$ had score $3.16 .7 \%$ had score 1 in lobular (focal) inflammation, $66.7 \%$ had score 4 and $16.6 \%$ had score 3 . Interface inflammation was score 1 in $100 \%$ of mice. All infected treated groups didn't show interface inflammation and the portal and lobular inflammation was reduced

Details were given in tables $(2 \& 3)$ and figures $(1,2,3,4, \& 5)$. 
Table 2: T. gondii tachyzoites $/ 20 \mu 1$ IP fluid in infection control and infected treated groups

\begin{tabular}{|c|c|c|c|}
\hline Group & Mean \pm SEM & $\%$ Reduction & P value \\
\hline C & $42511 \pm 3926$ & -- & -- \\
\hline M & $2695 \pm 396$ & $93.66 \%$ & $0.003^{*}$ \\
\hline B & $736 \pm 102$ & $98.27 \%$ & $<0.001^{*}$ \\
\hline S & $6363 \pm 1491$ & $85.03 \%$ & 0.179 \\
\hline B+S1 & $5832 \pm 1169$ & $86.28 \%$ & 0.106 \\
\hline B+S2 & $703 \pm 525$ & $98.35 \%$ & $0 *$ \\
\hline \multicolumn{4}{|c}{ *(P value significant $<0.05)$}
\end{tabular}

(C: infection control, M (macrolides): spiramycin $200 \mathrm{mg} / \mathrm{kg}$ ), B (bisphosphonates): risedronate sodium $0.4 \mathrm{mg} / \mathrm{kg}, \mathrm{S}$ (statins): atorvastatin $40 \mathrm{mg} / \mathrm{kg}, \mathrm{B}+\mathrm{S} 1$ (bisphosphonates + statins $1^{\text {st }}$ combination): risedronate sodium $0.01 \mathrm{mg} / \mathrm{kg}+$ atorvastatin $1.25 \mathrm{mg} / \mathrm{kg}, \mathrm{B}+\mathrm{S} 2$ (bisphosphonates + statins $2^{\text {nd }}$ combination): risedronate sodium $0.2 \mathrm{mg} / \mathrm{kg}+$ atorvastatin $20 \mathrm{mg} / \mathrm{kg}$ )

\begin{tabular}{|c|c|c|c|c|c|c|c|}
\hline \multirow[b]{2}{*}{ Pathology } & \multirow[b]{2}{*}{ Score } & $\mathrm{C}$ & $\mathrm{M}$ & B & $\mathrm{S}$ & $\mathrm{B}+\mathrm{S} 1$ & $\mathrm{~B}+\mathrm{S} 2$ \\
\hline & & $\%$ & $\%$ & $\%$ & $\%$ & $\%$ & $\%$ \\
\hline \multirow{4}{*}{$\begin{array}{l}\text { Portal in- } \\
\text { flammation }\end{array}$} & 0 & $0 \%$ & $50 \%$ & $33.3 \%$ & $0 \%$ & $0 \%$ & $0 \%$ \\
\hline & 1 & $16.7 \%$ & $50 \%$ & $66.7 \%$ & $16.7 \%$ & $33.3 \%$ & $50 \%$ \\
\hline & 2 & $66.6 \%$ & $0 \%$ & $0 \%$ & $66.7 \%$ & $50 \%$ & $33.3 \%$ \\
\hline & 3 & $16.7 \%$ & $0 \%$ & $0 \%$ & $16.6 \%$ & $16.7 \%$ & $16.7 \%$ \\
\hline \multirow{5}{*}{$\begin{array}{l}\text { Lobular } \\
\text { inflammation }\end{array}$} & 0 & $0 \%$ & $50 \%$ & $66.7 \%$ & $0 \%$ & $0 \%$ & $0 \%$ \\
\hline & 1 & $0 \%$ & $50 \%$ & $33.3 \%$ & $33.3 \%$ & $53.3 \%$ & $66.6 \%$ \\
\hline & 2 & $0 \%$ & $0 \%$ & $0 \%$ & $50 \%$ & $16.7 \%$ & $33.3 \%$ \\
\hline & 3 & $16.7 \%$ & $0 \%$ & $0 \%$ & $0 \%$ & $0 \%$ & $0 \%$ \\
\hline & 4 & $66.7 \%$ & $0 \%$ & $0 \%$ & $16.7 \%$ & $0 \%$ & $0 \%$ \\
\hline
\end{tabular}

\section{Discussion}

In this study, in the acute Toxoplasma RH strain infected mice treated with the spiramycin alone at a dose of $200 \mathrm{mg} / \mathrm{kg} /$ day for 5 days showed significant reduction of $T$. gondii tachyzoites number with a reduction of $93.66 \%(\mathrm{P}=0.003)$. This result agreed with Etewa et al. (2018) in Egypt who reported significant reduction in tachyzoites number in spiramycin treated RH strain infected mice with a rate of $94.59 \%$. However, both results disagreed with Grujić et al. (2005) in Be lgrade who used type-1 (RH) or type-2 (Me49) strain of $T$. gondii and found that mice treated with spiramycin at $100 \& 20$ $\mathrm{mg} / \mathrm{kg}$ for a week showed a limited effect without ability to prevent the infected mice death. Nevertheless, Hagras et al. (2019) in Egypt who found highest efficiency reduction in tachyzoites number in spiramycinloaded chitosan nanoparticles treated $\mathrm{RH}$ strain infected mice. They concluded that the non-toxic nature and the anti-parasitic effect of both spiramycin-metronidazole and spiramycin-loaded chitosan (CS) and spiramycin recommended the use of spiramycinloaded CS NPs a potential drug for the treatment of human toxoplasmosis.

In the present study, mice treated with ris- edronate sodium at a dose of $0.4 \mathrm{mg} / \mathrm{kg} /$ day for 5 days showed a significant reduction of $T$. gondii tachyzoites number to $98.27 \%$ ( $\mathrm{P}<$ 0.001). Yardley et al. (2002) in the United Kingdom studied the in-vivo activities of 3 bisphosphonates against Leishmania donovani and Toxoplasma gondii and alendronate was essentially inactive against both parasites. They concluded that pamidronate was active against $L$. donovani by IV administration, and risedronate had a $50 \%$ effective dosage of five $2.6-\mathrm{mg} / \mathrm{kg} /$ body weight intraperitoneal doses, but was less effective against T. gondii-infected mice. Also, Shubar et al. (2008) in Germany used newly synthesized bisphosphonates $2 \mathrm{~F}, 3 \mathrm{~B}, 91 \mathrm{~A} \& 282 \mathrm{~A}$ reported excellent therapeutic activity and low toxicity. They added that the anti-parasitic drugs may be promising agents for patients with acute and reactivated toxoplasmosis. Also, Szajnman et al. (2017) in Argentina reported that the most potent compound 22 (11,1-bisphosphonic acid) is a sulfone-containing compound, which had a $50 \%$ effective concentration $\left(\mathrm{EC}_{50}\right)$ of $0.11 \pm 0.02 \mu \mathrm{M}$ against intracellular tachyzoites, and with low toxicity when tested in tissue culture with a selectivity index of $>2,000$. Compound 22 also showed high activity in vivo in 
a toxoplasmosis mouse model. The compound inhibited the Toxoplasma farnesyl diphosphate synthase (TgFPPS), but the concentration must be $50 \%$ of the enzymatic activity $\left(\mathrm{IC}_{50}\right)$ was higher than the concentration that inhibited $50 \%$ of growth. They concluded that it is an excellent novel compound that could lead to the development of potent agents against apicomplexan parasites. Besides, Li et al. (2017) in USA reported that bisphosphonates are widely used for bone disorders treatment. They studied the synergism of several bisphosphonates with statins both in vitro and in vivo, and concluded that it was possible to develop drug combinations that act synergistically by inhibiting host and $T$. gondii enzymes in vitro and in vivo. But, this disagreed with Nair et al. (2011) in USA who reported that in spite of the fact that apicoplast is home to a 1-deoxy-D-xylulose-5-phosphate pathway for isoprenoid precursor synthesis, which was believed to be the most conserved function of apicoplast, and fosmidomycin, a specific pathway inhibitor as an effective antimalarial. But, fosmidomycin didn't affect most of the other apicomplexans, especially $T$. gondii the para site plasma membrane is a critical barrier to drug uptake fosmidomycin.

In the present study, acute infected mice treated with atorvastatin at a dose of $40 \mathrm{mg} /$ $\mathrm{kg} /$ day for 5 days showed insignificant reduction of $T$. gondii tachyzoites number to $85.03 \%(\mathrm{P}=0.179)$. This agreed with Cortez et al. (2009) found that the in vitro activity of statins stopped $T$. gondii multiplication in Swiss mice macrophages. Also, Nishikawa et al. (2011) in Japan found that T. gondii growth was suppressed by squalestatin, despite mevalonate producing isoprenoid intermediates in host cells. They concluded that lovastatin, compactin and squalestatin have anti-Toxoplasma activities and that the host cholesterol synthesis contributed to parasite growth in macrophages. Li et al. (2013) reported that in vivo Atorvastatin in Swiss mice infected with $T$. gondii strain $\mathrm{RH}$ increased their survival for $<30$ days. Also, the pres- ent result agreed with Li et al. (2017) they treated mice with atorvastatin $(10 \& 20 \mathrm{mg} /$ $\mathrm{kg} /$ body/day) found that infection led to only a marginal survival difference between control and treated groups $24 \mathrm{hr}$ after infection with 20 parasites of type I strain. They added that atorvastatin $(20 \mathrm{mg} / \mathrm{kg} /$ day $)$ protected $80 \%$ of $T$. gondii mice infected with 20 parasites of $\triangle$ TgFPPS strain, but same dose was ineffective against 100 parasites infection.

In the present study, combination between risedronate sodium and atorvastatin at a dose of $0.01 \mathrm{mg} / \mathrm{kg} /$ day $\& 1.25 \mathrm{mg} / \mathrm{kg} /$ day respectively for 5 days showed an insignificant reduction of $T$. gondii tachyzoites to $86.28 \%$ $(\mathrm{P}=0.106)$, but combination between risedronate sodium and atorvastatin at a dose of $0.2 \mathrm{mg} / \mathrm{kg} /$ day and $20 \mathrm{mg} / \mathrm{kg} /$ day respectively for 5 days showed a significant reduction in number of tachyzoites to $98.35 \%(\mathrm{P}=0.000)$ denoting synergistic effect between combined dose was better than that obtained from spiramycin $200 \mathrm{mg} / \mathrm{kg} /$ day treated mice. This agreed with Li et al. (2017) who found that bisphosphonates and statins combination has a more powerful effect rather than usage of each drug alone, but they found more synergism at low dose combination.

In the present study, histopathological examination of acute infected mice groups treated with spiramycin $200 \mathrm{mg} / \mathrm{kg} /$ day for 5 days, liver tissue showed much less inflammatory reactions compared to corresponding infection controls. This agreed with Etewa et al. (2018) who found that liver sections from RH strain acute infected mice and treated with spiramycin showed an obvious reduction of the inflammatory response with mild hepatocytes inflammation and necrosis.

In the present study, mice treated with risedronate sodium at a dose of $0.4 \mathrm{mg} / \mathrm{kg} / \mathrm{day}$ for 5 days, liver tissue showed the least inflammatory reactions in acute toxoplasmosis. This agreed with Garzoni et al. (2004) in Brazil who found that heart tissues of mice infected with Trypanosoma cruzi (same isoprenoid pathway as $T$. gondii) and treated with risedronate showed normal cardiac tissue, 
with very rare amastigote nests and small mononuclear cell infiltrates. They added that risedronate could be a useful lead compound for the development of new drugs effective against Chagas' disease.

\section{Conclusion}

Spiramycin, the routinely used drug in treatment of toxoplasmosis, showed significant reduction of the number of tachyzoites, but its therapeutic effect was less than that obtained by the drug combination in acute toxoplasmosis infected mice. Thus, combination of bisphosphonates and statins may represent a good alternative treatment.

Moreover, the infected mice treated with risedronate sodium alone, showed a significant histopathological improvement in the pathology of the examined liver tissue. Accordingly, risedronate sodium alone may represent a promising anti-Toxoplasma treatment.

\section{Recommendations}

Conduct extensive studies using other Bisphosphonates and statins with different doses and prolonged regimens may highly increase its efficacy against Toxoplasma infection. In vivo studies on the efficacy of risedronate sodium alone and/or combined risedronate sodium and atorvastatin treating acute Toxoplasma infected patients are ongoing and will be published in due time elsewhere.

Toxoplasmosis health education must be tailored to women of childbearing age that may help to prevent infection.

\section{References}

Abbas, SA, Basalamah, A, Serebour, F, Alfonso, M, 1986: Toxoplasma gondii antibodies in Saudi women and outcome of congenital infection among new-borne in Saudi Arabia. Saudi Med. J. 7:346-54.

Abbas, IE, I Villena, I, J P Dubey, JP, 2020: A review on toxoplasmosis in humans and animals from Egypt. Parasitology 147, 2:135-59

Abdel Hamed, EF, Mostafa, NE, Saleh, AA, Salama, MA, Ibrahim, SM, et al, 2019: Artesunate loaded Nano fiber and its combinations with spiramycin for treatment of murine toxoplasmosis. J. Egypt. Soc. Parasitol. 49, 1:135-44.

Al-Kappany, YM, Rajendran, C, Ferreira, LR, Kwok, OC, Abu-Elwafa, SA, et al, 2010:
High prevalence of toxoplasmosis in cats from Egypt: isolation of viable Toxoplasma gondii, tissue distribution, and isolate designation. J. Parasitol. 96, 6:1115-8.

Al-Dakhil, MA, Morsy, TA, 1996: Natural Toxoplasma infection sought in the Indian grey mongoose trapped in the eastern region, Saudi Arabia. J. Egypt. Soc. Parasitol. 26:645-52.

Ashburn, TT, Thor, KB, 2004: Drug repositioning: Identifying and developing new uses for existing drugs. Nat. Rev. Drug Discovery 3, 8: 673-83.

Azevedo Silva, L, Fernandes, MD, Machado, AS, Reis-Cunha, JL, Bartholomeu, DC, et al, 2019: Efficacy of sulfadiazine and pyrimetamine for treatment of experimental toxoplasmosis with strains obtained from human cases of congenital disease in Brazil. Exp. Parasitol. 202:7-14

Berger, F, Goulet, V, Le Strat, Y, Desenclos, J C, 2009: Toxoplasmosis among pregnant women in France: Risk factors and change of prevalence between 1995 and 2003. Rev. Epidemiol. Sante Publ. 57:241-8.

Boyom, FF, Fokou, PV, Tchokouaha, LR, Spangenberg, T, Mfopa, AN, et al, 2014: Repurposing the open access malaria box to discover potent inhibitors of Toxoplasma gondii and Entamoeba histolytica. Antimicrob. Agents Chemother. 58:5848-52.

Cortez, E, Stumbo, AC, Oliveira, M, Barbosa, HS, Carvalho, L, 2009: Statins inhibit Toxoplasma gondii multiplication in macrophages in vitro. Inter. J. Antimicrob. Agents 33, 2:185-6.

D'angelo, JG, Bordon, C, Posner, GH, Yolken, R, Jones-Brando, L, 2008: Artemisinin derivatives inhibit Toxoplasma gondii in vitro at multiple steps in the lytic cycle. J. Antimicrob. Chemother. 63, 1: 146-50.

Dobromylskyj, PPA, Flecknell, BD, Lascelles, PJ, Pascoe, P, Taylor, A, et al, 2000: Management of postoperative and other acute pain. In: Pain Management in Animals. By: P. Flecknell, A. Waterman-Pearson. W.B. Saunders, London.

Dolores, E, Jitender, H, Dubey, P, Xiao, L, Ryan, U, et al, 2015: Important foodborne protists: Toxoplasma gondii. In: Biology of Food-bo rne Parasites. Taylor and Francis group, CRC. Press.

Drury, RAB, Wallington, EA, 1980: Carleton' s Histological Technique. $5^{\text {th }}$ ed., Oxford University Press. Oxford, New York, \& Toronto.

Eissa, MM, El-Azzouni, MZ, Mady, RF, Fat- 
hy, FM, Baddour, NM, 2012: Initial characterization of an autoclaved Toxoplasma vaccine in mice. Exp. Parasitol. 131, 3:310-6.

Erhirhie, EO, Ekene, NE, Ajaghak, DL, 2014: Guidelines on dosage calculation and stock solution preparation in experimental animals' studies. J. Nat. Sci. Res. 4, 18:100-6.

Etewa, SE, El-Maaty, DAA, Hamza, RS, Metwaly, AS, Sarhan, MH, et al, 2018: Assessment of spiramycin-loaded chitosan nanoparticles treatment on acute and chronic toxoplasmosis in mice. J. Parasit. Dis. 42, 1:102-13.

Garcia, LS, 2007: Diagnostic Medical Parasitology. $5^{\text {th }}$ ed.; ASM Press, Washington.

Garzoni, LR, Waghabi, MC, Baptista, MM, De Castro, SL, Nazareth, LM, et al, 2004: Antiparasitic activity of risedronate in a murine model of acute Chagas' disease. Inter. J. Antimicrob. Agents 23, 3:286-90.

Grujić, J, Djurković-Djaković, O, Nikolić, A, Klun, I, Bobić, B, 2005: Effectiveness of spiramycin in murine models of acute and chronic toxoplasmosis. Inter. J. Antimicrob. Agents 25, 3: 226-30.

Hagras, NAE. Allam, AF, Farag, HF, Osman, MM, Shalaby, TI, et al, 2019: Successful treatment of acute experimental toxoplasmosis by spiramycin-loaded chitosan nanoparticles. Exp. Parasitol. 204:107717. doi: 10.1016/j.exppara. 2019.107717

Jones, J, Lopez, A, Wilson, M, Jones, J, et al, 2003: Congenital toxoplasmosis. Am. Fam. Physician 67, 10:2131-8.

Kassem, HH, Morsy, TA, 1991: The prevalence of anti-Toxoplasma antibodies among pregnant woman in Benghazi (S.P.L.A.J.), Libya. J. Egypt. Soc. Parasitol. 21, 1:69-74.

Li, ZH, Ramakrishnan, S, Striepen, B, Moreno, SN, 2013: Toxoplasma gondii relies on both host and parasite isoprenoids and can be rendered sensitive to atorvastatin. PLoS Pathog. 9, 10:e1003665.

Li, ZH, Li, C, Szajnman, SH, Rodriguez, JB, Moreno, SN, 2017: Synergistic activity between statins and bisphosphonates against acute experimental toxoplasmosis. Antimicrob. Agents Chemother. 61, 8:e02628-16.

Liang, YS, Bruce, JI, Botd, DA, 1987: Proceeding of the First Sino-American Symposium, 1: 34-48.

London, E, East, S, 2001: Storage, Stability and in-Use Shelf-Life Guidelines for Non-Sterile Medicines. London, Eastern and South East Spe- cialist Pharmacy Services Quality Assurance Service.

McAuley, JB, Boyer, KM, Remington, JS, Mc Leod, RL, 2009: Toxoplasmosis. In: Textbook of Pediatric Infectious Diseases, $6^{\text {th }}$ ed, Feigin, RD, Cherry, JD, Demmler-Harrison, GJ, Kaplan, SL, (Eds), Saunders, Philadelphia

Michael, SA, El Refaii, A, Morsy, TA, 1979: Experimental infection of cats with RH strain of Toxoplasma gondii. J. Egypt. Soc. Parasitol. 9, 1:175-81.

Montazeri, M, Sharif, M. Sarvi, S, Mehrzadi, S, Amadpour, E, et al, 2017: A Systematic review of in vitro and in vivo activities of anti-Toxoplasma Drugs and Compounds (2006-2016). Front Microbiol. 8:25-9.

Moreno, SN, Li, ZH, 2008: Anti-infectives targeting the isoprenoid pathway of Toxoplasma gondii. Expe. Opin. Therap. Targ.12, 3:253-63.

Morsy, TA, Michael, SA, 1980: Toxoplasmosis in Jordan. J. Egypt. Soc. Parasitol. 10, 2:457-70. Nair, SC, Brooks, CF, Goodman, CD, Strurm, A, McFadden, GI, et al, 2011: Apicoplast isoprenoid precursor synthesis and the molecular basis of fosmidomycin resistance in Toxoplasma gondii. J. Exp. Med. 208, 7:1547-59.

Nishikawa, Y, Ibrahim, HM, Kameyama, K, Shiga, I, Hiasa, J, et al, 2011: Host cholesterol synthesis contributes to growth of intracellular Toxoplasma gondii in macrophages. J. Vet. Med. Sci. Tokyo, 73, 5:633-9.

Pagheh, AS, Sarvi, S, Sharif, M, Rezaei, F, Ahmadpour, E, et al, 2020: Toxoplasma gondii surface antigen 1 (SAG1) as a potential candidate to develop vaccine against toxoplasmosis: A systematic review. Compar. Immunol. Microbiol. Infect. Dis. 69: 101414.

Saleh, AMA, Ali, HA, Ahmed, SAM, Hosny, S M, Morsy, TA, 2014: Screening of Toxoplasma gondii infection among childbearing age females and assessment of nurses' role in prevention and control of toxoplasmosis. J. Egypt. Soc. Parasitol. 44, 2:329-42

Saleh, AMA, Al-Agroudi, MA, Morsy, TA, 2016: Occupational, nosocomial or hospital acquired toxoplasmosis. J. Egypt. Soc. Parasitol. 46, 2:407-18

Shoura, MA, Morsy, TA, EI Dasouqui, IT, 1973: Toxoplasmin skin tests in Riyadh, Saudi Arabia. J. Trop. Med. Hyg. 76, 10:254

Shubar, HM, Mayer, JP, Hopfenmüller, W, Liesenfeld, O, 2008: A new combined flow-cytometry-based assay reveals excellent activity ag- 
ainst Toxoplasma gondii and low toxicity of new bisphosphonates in vitro and in vivo. J. Antimicrob. Chemother. 61, 5:1110-9.

Szajnman, SH, Galaka, T, Li, ZH, Li, C, Howell, NM, et al, 2017: In vitro and in vivo activities of sulfurcontaining linear bisphosphonates against apicomplexan parasites. Antimicrob. Agents Chemother. 61, 2:e01590-16.

Theise, ND, 2007: Liver biopsy assessment in chronic viral hepatitis: A personal, practical approach. Mod. Pathol. 20: 3-14.

Yardley, V, Khan, AA, Martin, MB, Slifer, T R, Araujo, FG, et al, 2002: In vivo activities of farnesyl pyrophosphate synthase inhibitors agai- nst Leishmania donovani and Toxoplasma gondii. Antimicrob. Agents Chemother. 46, 3:92931 .

Wishahy, AO, Rifaat, MA, Morsy, TA, El Naggar, BA, 1971: Studies on toxoplasmosis in Egyptian children, report on the effect of treatment in positive cases. Gaz. Egypt. Paediatr. Assoc. 19, 4:209-18.

Zhang, JL, Si, HF, Shang, XF, Zhang, XK, Li, B, et al, 2019: New life for an old drug: Invitro and in-vivo effects of the anthelmintic drug niclosamide against Toxoplasma gondii RH strain. Inter. J. Parasitol. Drugs Drug Resist. 9:2734.

\section{Explanation of figures}

Fig. 1: T. gondii tachyzoites stained with Giemsa in IP fluid sample from IC group (x100 objective lens)

Fig. 2: Normal liver with preserved architecture showed hepatocytes (black arrow), arranged in thin plates with patent central vein (red arrow), sinusoids (blue arrow) and normal portal tract (Yellow arrow), (x10, H\&E stain).

Fig. 3: Histopathological examination of liver tissue from infection control mice showed a single portal tract with marked lymphocytic cellular infiltrate (black arrow) (Score 3), (x10, H\&E stain).

Fig. 4: Histopathological examination of liver tissue from acute infected mice treated with spiramycin $200 \mathrm{mg} / \mathrm{kg} /$ day showed 2 foci of lobular (focal) inflammation (Score 1), (x40, H\&E stain).

Fig. 5: Histopathological examination of liver tissue from acute infected mice treated with risedronate sodium $0.4 \mathrm{mg} / \mathrm{kg} / \mathrm{day}$ showed a single focus of lobular (focal) inflammation (Score 1) with preserved architecture (x40, H\&E stain).

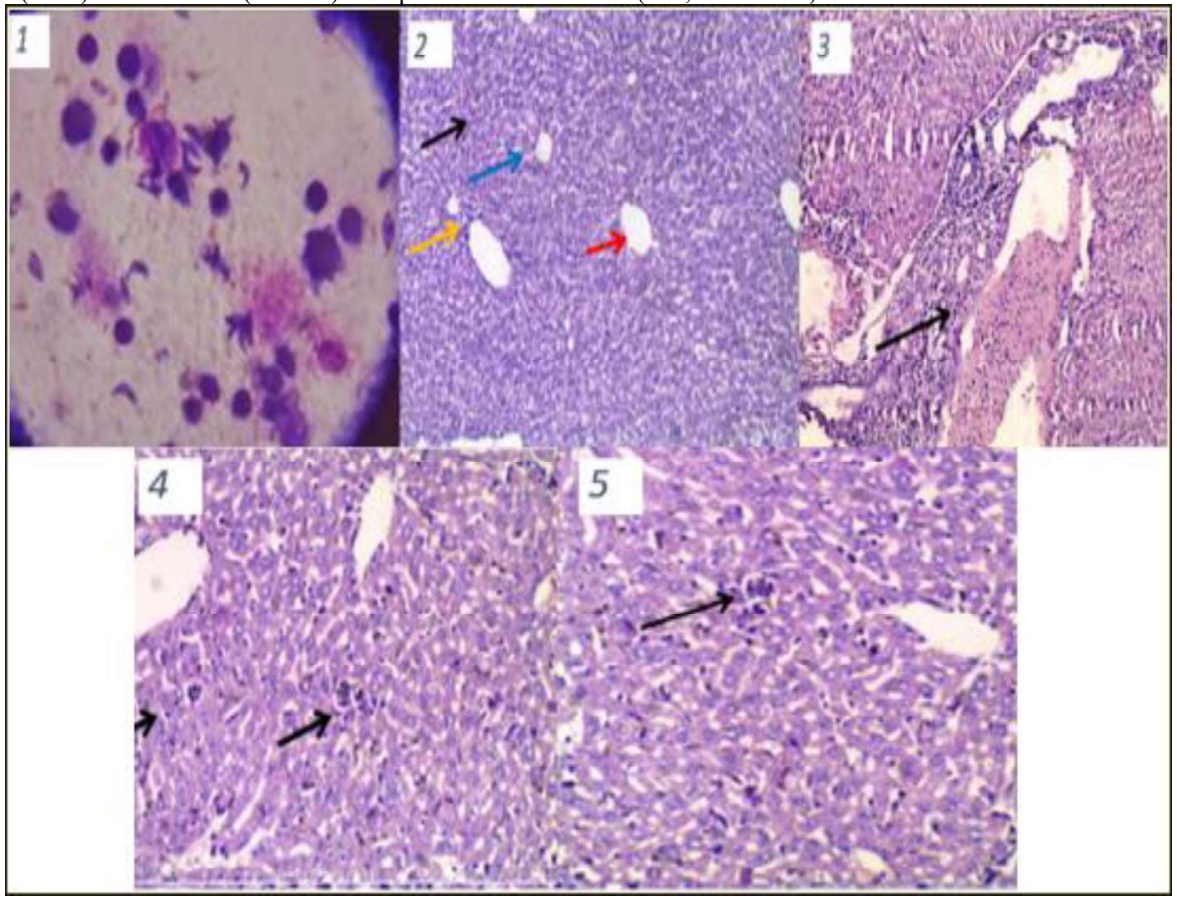

